\title{
Effect of variation in the proportion of solid- and liquid-associated rumen bacteria in duodenal contents on the estimation of duodenal bacterial nitrogen flow*
}

\author{
B. Vlaeminck ${ }^{1}$, V. Fievez ${ }^{1,3}$, D. Demeyer ${ }^{1}$ and R.J. Dewhurst ${ }^{2,4}$ \\ ${ }^{1}$ Laboratory for Animal Nutrition and Animal Product Quality, Ghent University \\ Proefhoevestraat 10, 9090 Melle, Belgium \\ ${ }^{2}$ Institute of Grassland and Environmental Research \\ Plas Gogerddan, Aberystwyth, Ceredigion SY23 3EB, UK
}

(Received 16 August 2006; accepted 2 February 2007)

\begin{abstract}
The aim of this research was to examine to what extent variation in the relative proportions of solid- (SAB) and liquid-associated rumen bacteria (LAB) in duodenal bacteria have an impact on the estimation of duodenal flow of bacterial N. For this, four dairy cows were fed diets varying in forage: concentrate ratio (80:20, 65:35, 50:50 and 35:65). SAB and LAB were separated from rumen contents four $\mathrm{h}$ after the morning feeding. Adenine, cytosine and odd and branched-chain fatty acids were determined both in $\mathrm{SAB}$ and $\mathrm{LAB}$ and used to estimate bacterial $\mathrm{N}$ flow. Bacterial $\mathrm{N}$ flows were also calculated using a SAB:LAB ratio in duodenal bacteria, as estimated from the odd and branched-chain fatty acid pattern. Compared with calculations based on the estimated SAB:LAB ratio, estimations based on SAB or LAB only as a bacterial reference on average over- and underestimated bacterial $\mathrm{N}$ flow by 37 and $55 \mathrm{~g} \mathrm{~N} / \mathrm{d}$, respectively $(\mathrm{P}<0.05)$ when cytosine or adenine were used as bacterial marker. In contrast, due to the small differences in the OBCFA:N ratio between SAB and LAB, these differences were less than $15 \mathrm{~g} / \mathrm{d}$ when OBCFA were used as bacterial marker. The results suggest that, depending on the marker used, changes in the proportions of SAB and LAB can have a substantial impact on estimated duodenal flow of bacterial $\mathrm{N}$.
\end{abstract}

KEY WORDS: bacterial N, solid associated bacteria, liquid associated bacteria, rumen, odd- and branched-chain fatty acids

\footnotetext{
${ }^{*}$ Funded by the UK Ministry of Agriculture, Fisheries and Food (now Department for Environment, Food and Rural Affairs)

${ }^{3}$ Corresponding author: e-mail: veerle.fievez@UGent.be

${ }^{4}$ Current address: Agriculture and Life Sciences Division, Lincoln University, Canterbury, New Zealand
} 


\section{INTRODUCTION}

Estimates of rumen bacterial $\mathrm{N}$ synthesis $(\mathrm{MN})$ have been calculated from marker:bacterial $\mathrm{N}$ ratios. These ratios have generally been established in bacteria isolated from the liquid phase of rumen digesta, and it has tacitly been assumed that the same relationship holds in the total population leaving the rumen. However, differences between liquid- (LAB) and solid-associated (SAB) bacteria for marker ratios have been reported (e.g., Dewhurst et al., 2000; Carro and Miller, 2002). The impact of using both $\mathrm{SAB}$ and $\mathrm{LAB}$ in the calculation of MN will depend on the relative contribution of both bacterial fractions to the duodenal flow of bacterial matter. Although there is little information about the contribution of SAB and $\mathrm{LAB}$ to total bacterial flow, the relative proportion of SAB and LAB in the rumen can be affected by dietary factors. Indeed, Faichney (1980) reported that the proportion of $\mathrm{SAB}$ reached $90 \%$ in sheep fed forage only whereas it declined to $50 \%$ for steers fed equal proportions of forage and concentrate (Merry and McAllan, 1983). Hence, variation in relative proportions of SAB and LAB could largely influence estimates of rumen microbial synthesis when either SAB or LAB marker: $\mathrm{N}$ ratios are used for calculations.

Recently, linear programming was used to partition $\mathrm{N}$ flowing to the duodenum into feed, bacteria, protozoa, and endogenous fractions (Shabi et al., 2000; Reynal et al., 2003). Using the same approach, we have calculated the relative proportions of SAB and LAB in duodenal content (Vlaeminck et al., 2006). For this, the odd and branched-chain fatty acids (OBCFA) pattern of SAB and LAB were used to estimate the relative proportions of both bacterial isolates in duodenal bacteria and found that the proportion of SAB ranged from 49.3 to $84.5 \%$, and decreased with decreasing proportion of dietary forage (Vlaeminck et al., 2006). In the current paper, we used the latter results to illustrate the importance of this SAB:LAB ratio in estimating duodenal flow of MN.

\section{MATERIAL AND METHODS}

Experimental procedures were described previously (Moorby et al., 2006). Briefly, four rumen- and duodenal-fistulated dairy cows in mid-lactation were offered diets varying in forage:concentrate ratio $(80: 20,65: 35,50: 50,35: 65$ on a DM basis; Moorby et al., 2006) in a $4 \times 4$ Latin square. Dietary treatments were based on ad libitum access to ryegrass silage and a standard dairy concentrate. Diet F:C ratios were achieved by measuring ad libitum silage DMI on a daily basis (silage was offered to allow at least $10 \%$ refusals), and allocating the appropriate amount of concentrate to each animal based on a rolling average of their silage 
DMI from the previous $3 \mathrm{~d}$ of the experiment. Each experimental period lasted for 28 days of which the first 2 weeks for adaptation. Fresh forage was distributed daily at $09.00 \mathrm{~h}$ whereas concentrates were distributed twice daily in equal portions at milking (08.00 and $16.00 \mathrm{~h})$.

Rumen and duodenal samples were taken during the final week of each experimental period. Rumen emptying was done by hand, on the final day of each period $4 \mathrm{~h}$ after feeding. Samples $(5 \%)$ of rumen contents were taken throughout the emptying procedure for analysis and rumen contents were weighed and returned to the rumen within $30 \mathrm{~min}$ of commencement. The procedure for isolation of LAB and SAB is described in Vlaeminck et al. (2006). Duodenal sampling was performed over two consecutive days using the automated equipment described by Evans et al. (1981). Duodenal bacteria were separated from a reconstituted sample by differential centrifugation (Vlaeminck et al., 2006). Duodenal flows were determined based on the double marker technique as described by Faichney (1992). Cytosine, adenine and OBCFA were used as microbial marker and were determined in rumen bacteria and duodenal digesta. Cytosine and adenine were analysed using the method described by Cozzi et al. (1993) and OBCFA as described by Vlaeminck et al. (2006). Total bacterial $\mathrm{N}$ flow at the duodenum was calculated by dividing the marker flow by the marker: $\mathrm{N}$ ratio in mixed rumen bacteria. The latter was calculated as $\left(\mathrm{a} \times\right.$ marker $\left._{\mathrm{SAB}}+\mathrm{b} \times \operatorname{marker}_{\mathrm{LAB}}\right) /\left(\mathrm{a} \times \mathrm{N}_{\mathrm{SAB}}+\mathrm{b} \times \mathrm{N}_{\mathrm{LAB}}\right)$ with $\mathrm{a}$ and $\mathrm{b}$ the relative proportion of $\mathrm{SAB}$ and $\mathrm{LAB}$ in duodenal content, respectively. The relative proportions of $\mathrm{SAB}$ and $\mathrm{LAB}$ in duodenal content were estimated using OBCFA of $\mathrm{SAB}$ and $\mathrm{LAB}$ isolated from rumen content and of duodenal bacteria as described in Vlaeminck et al. (2006). Differences in the calculated bacterial $\mathrm{N}$ flow using marker: $\mathrm{N}$ ratios of either $\mathrm{SAB}$ or $\mathrm{LAB}$ or the estimated ratios in mixed rumen bacteria were analysed according to:

$$
\mathrm{Y}_{\mathrm{ijkl}}=\mu+\mathrm{T}_{\mathrm{i}}+\mathrm{P}_{\mathrm{j}}+\mathrm{C}_{\mathrm{k}}+\mathrm{B}_{1}+\mathrm{TB}_{\mathrm{il}}+\mathrm{CB}_{\mathrm{kl}}+\varepsilon_{\mathrm{ijk} k}
$$

where $\mathrm{Y}_{\mathrm{ijk}}$ is the individual observation, $\mu$ the overall mean, $\mathrm{T}_{\mathrm{i}}$ the effect of dietary treatment, $P_{j}$ the effect of experimental period, $C_{k}$ the effect of cow, $B_{1}$ the effect of bacterial reference, $\mathrm{TB}_{\mathrm{il}}$ the interaction between treatment and bacterial reference, $\mathrm{CB}_{\mathrm{kl}}$ the interaction between bacterial reference and cow and $\varepsilon_{\mathrm{ijk}}$ the residual error.

The effect of bacterial marker was analysed according to:

$$
\mathrm{Y}_{\mathrm{ijkl}}=\mu+\mathrm{T}_{\mathrm{i}}+\mathrm{P}_{\mathrm{j}}+\mathrm{C}_{\mathrm{k}}+\mathrm{M}_{1}+\mathrm{TM}_{\mathrm{il}}+\mathrm{CM}_{\mathrm{kl}}+\varepsilon_{\mathrm{ijkl}}
$$

with $M_{1}$ the effect of bacterial marker and other abbreviations as before.

All statistical analyses were performed using SPSS 12.0 (SPSS software for Windows, release 12.0., SPSS, Inc., USA). 


\section{RESULTS AND DISCUSSION}

The effect of dietary forage:concentrate ratio on $\mathrm{MN}$ was discussed in detail previously (Moorby et al., 2006). The overall estimated duodenal flow of MN was on average 168, 222 and $197 \mathrm{~g} / \mathrm{d}$ using marker: $\mathrm{N}$ ratios of LAB and cytosine, adenine and OBCFA as bacterial marker, respectively (Table 1). When

Table 1. Estimated bacterial $\mathrm{N}$ flow to the duodenum using marker: $\mathrm{N}$ ratios of mixed duodenal bacteria, as estimated from the ratio solid (SAB) to liquid-associated rumen bacteria (LAB) (Vlaeminck et al., 2006), vs marker:N ratios of SAB or LAB only for three different bacterial markers

\begin{tabular}{|c|c|c|c|c|c|}
\hline \multirow{2}{*}{ Marker } & \multicolumn{3}{|c|}{ SAB:LAB ratio } & \multirow{2}{*}{$\mathrm{SEM}^{2}$} & \multirow{2}{*}{$\mathrm{P}$} \\
\hline & calculated $^{1}$ & $1: 0$ & $0: 1$ & & \\
\hline Cytosine & $209^{\mathrm{b}, \mathrm{A}}$ & $246^{\mathrm{c}, \mathrm{A}}$ & $168^{\mathrm{a}, \mathrm{A}}$ & 7.2 & 0.001 \\
\hline Adenine & $283^{\mathrm{b}, \mathrm{C}}$ & $335^{\mathrm{c}, \mathrm{B}}$ & $222^{\mathrm{a}, \mathrm{B}}$ & 9.1 & 0.001 \\
\hline OBCFA & $233^{\mathrm{b}, \mathrm{B}}$ & $239^{\mathrm{b}, \mathrm{A}}$ & $220^{\mathrm{a}, \mathrm{B}}$ & 2.5 & 0.040 \\
\hline SEM $^{1}$ & 7.4 & 10.6 & 5.3 & & \\
\hline $\mathrm{P}$ & 0.001 & 0.001 & 0.002 & & \\
\hline
\end{tabular}

${ }^{1} \mathrm{SAB}: \mathrm{LAB}$ ratio in duodenal bacteria calculated from odd and branched-chain fatty acid pattern (Vlaeminck et al., 2006)

${ }^{2}$ standard error of the mean

a, b, c mean values lacking a common superscript within a row differ significantly $(\mathrm{P}<0.05)$

A, B, C mean values lacking a common superscript within a column differ significantly $(\mathrm{P}<0.05)$

using the SAB reference ratios for cytosine, adenine and OBCFA as bacterial marker, daily duodenal flows of MN were on average 77.6, 112.8 and $18.7 \mathrm{~g}$ higher, respectively (Table 1). The large impact of bacterial reference (SAB vs $\mathrm{LAB}$ ) on estimated duodenal flow of $\mathrm{MN}$ is well known and is related to differences in the marker: $\mathrm{N}$ ratio in the different bacterial fractions (Dewhurst et al., 2000). Indeed, the respective marker: $\mathrm{N}$ ratios for purine and pyrimidinic bases in SAB were 32 and $29 \%$ lower compared to LAB (Table 2), possibly

Table 2. Bacterial content of $\mathrm{N}$, cytosine, adenine and odd and branched-chain fatty acids $(\mathrm{mg} / \mathrm{g}$ $\mathrm{DM})$ and marker:N ratio (g/g) of solid- (SAB) and liquid-associated rumen bacteria (LAB)

\begin{tabular}{lcccc}
\hline Item & LAB & SAB & SEM $^{1}$ & P \\
\hline $\mathrm{N}$ & 78.5 & 86.7 & 1.42 & 0.001 \\
Cytosine & 6.08 & 3.37 & 0.176 & 0.001 \\
Adenine & 8.60 & 4.60 & 0.203 & 0.001 \\
OBCFA $^{2}$ & 9.57 & 7.01 & 0.172 & 0.001 \\
Cytosine: & 0.062 & 0.043 & 0.003 & 0.001 \\
Adenine: & 0.087 & 0.059 & 0.003 & 0.001 \\
OBCFA:N & 0.096 & 0.090 & 0.003 & 0.038 \\
\hline
\end{tabular}

${ }^{1}$ standard error of the mean differences between SAB and LAB

${ }^{2}$ odd and branched-chain fatty acids 
reflecting differences in growth rate, nutrient availability and/or bacterial species (Volden et al., 1999; Carro and Miller, 2002). Interestingly, the ratio OBCFA:N in $\mathrm{SAB}$ was only $6 \%$ lower compared with LAB.

From the above, it is clear that changes in the proportions of $\mathrm{SAB}$ and $\mathrm{LAB}$ can have a substantial impact on the estimated duodenal flow of MN. RodríguezPrado et al. (2004) suggested that many of the estimates of MN changed more because of the bacterial isolate considered than because of the main dietary factors studied. In addition, Martin et al. (1996) stated that information about the relative contributions of the different microbial populations to the small intestine is needed if accurate measurements of $\mathrm{MN}$ flow are to be obtained. In the current experiment, the relative proportions of SAB in duodenal content were estimated using a linear programming approach and ranged from 49.3 to $84.5 \%$ (Vlaeminck et al., 2006). Irrespective of the marker used, MN yield based on the estimated ratio of $\mathrm{SAB}: \mathrm{LAB}$ was different from estimations based on marker:N ratios of $\mathrm{SAB}$ or LAB (Table 1). Although duodenal flow of MN based on measured SAB: $\mathrm{LAB}$ ratio was highly correlated with $\mathrm{MN}$ yield based on $\mathrm{SAB}$ or $\mathrm{LAB}\left(\mathrm{r}_{\text {pearson }}>\right.$ 0.850 ), the lower accuracy resulted in a mean error of more than 35 and $50 \mathrm{~g} \mathrm{~N} / \mathrm{d}$ with cytosine and adenine as microbial marker, respectively. In contrast, due to the small difference in OBCFA: $N$ between $\mathrm{SAB}$ and $\mathrm{LAB}$, differences between flow of MN based on estimated SAB:LAB ratios and MN yield based on SAB or LAB was less than $15 \mathrm{~g} \mathrm{~N} / \mathrm{d}$.

Strikingly, differences in MN yield between the three markers were as high as changes brought about by the bacterial reference (Table 1). Hence, despite the substantial impact of the bacterial isolate on the estimated duodenal flow of MN, adjusting the latter using SAB:LAB ratios estimated from OBCFA profiles (Vlaeminck et al., 2006) seems of little value when observing these large differences among markers. Although it is impossible to state which marker method provides the most accurate estimate of MN flow (Stern et al., 1994), the current results suggest OBCFA to be more appropriate as bacterial marker compared with cytosine and adenine because of the small differences in OBCFA: $\mathrm{N}$ ratio between $\mathrm{SAB}$ and LAB.

\section{ACKNOWLEDGEMENTS}

Bruno Vlaeminck is a Postdoctoral Fellow of the Fund for Scientific ResearchFlanders (Belgium). 


\section{REFERENCES}

Carro M.D., Miller E.L., 2002. Comparison of microbial markers $\left({ }^{15} \mathrm{~N}\right.$ and purine bases) and bacterial isolates for the estimation of rumen microbial protein synthesis. Anim. Sci. 75, 315-321

Cozzi G., Bittante G., Polan C.E., 1993. Comparison of fibrous materials as modifiers of in situ ruminal degradation of corn gluten meal. J. Dairy Sci. 76, 1106-1113

Dewhurst R.J., Davies D.R., Merry R.J., 2000. Microbial protein supply from the rumen. Anim. Feed Sci. Tech. 85, 1-21

Evans R.T., Skelton K.V., Beever D.E., 1981. Portable equipment for the automatic sampling of duodenal contents from housed or grazing cattle. Lab. Pract. 30, 997-1000

Faichney G.J., 1980. Measurement in sheep of the quantity and composition of rumen digesta and of the fractional outflow rates of digesta constituents. Aust. J. Agr. Res. 31, 1129-1137

Faichney G.J., 1992. Effect of non-uniform distribution of particle-associated markers on the measurement of duodenal digesta flow by the double-marker technique. J. Agr. Sci. 118, 119120

Martin C., Bernard L., Michalet-Doreau B., 1996. Influence of sampling time and diet on amino acid composition of protozoa and bacterial fractions from bovine ruminal contents. J. Anim. Sci. 74, $1157-1163$

Merry R.J., McAllan A.B., 1983. A comparison of the chemical composition of mixed bacteria harvested from the liquid and solid fractions of rumen digesta. Brit. J. Nutr. 50, 701-709

Moorby J.M., Dewhurst R.J., Evans R.T., Danelón J., 2006. Effects of dairy cow diet forage proportion on duodenal nutrient supply and urinary purine derivative excretion. J. Dairy Sci. $89,3552-3562$

Reynal S.M., Broderick G.A., Ahvenjärvi S., Huhtanen P., 2003. Effect of feeding protein supplements of differing degradability on omasal flow of microbial and undegraded protein. J. Dairy Sci. 86, 1292-1305

Rodríguez-Prado M., Calsamiglia S., Ferret A., 2004. Effects of fiber content and particle size of forage on the flow of microbial amino acids from continuous culture fermenters. J. Dairy Sci. $87,1413-1424$

Shabi Z., Tagari H., Murphy M.R., Bruckental I., Mabjeesh S.J., Zamwel S., Celik K., Arieli A., 2000. Partitioning of amino acids flowing to the abomasums into feed, bacterial, protozoal and endogenous fractions. J. Dairy Sci. 83, 2326-2334

Stern M.D., Varga G.A., Clark J.H., Firkins J.L., Huber J.T., Palmquist D.L., 1994. Evaluation of chemical and physical properties of feeds that affect protein metabolism in the rumen. J. Dairy Sci. 77, 2762-2786

Vlaeminck B., Dewhurst R.J., Demeyer D., Fievez V., 2006. Effect of forage:concentrate ratio on fatty acid composition of rumen bacteria isolated from ruminal and duodenal digesta. J. Dairy Sci. $89,2668-2678$

Volden H., Mydland L.T., Harstad O.M., 1999. Chemical composition of protozoal and bacterial fractions isolated from ruminal contents of dairy cows fed diets differing in nitrogen supplementation. Acta Agr. Scand., Sect. A, Anim. Sci. 49, 235-244 